\title{
Nano-ion-exchangers - a new class of reactive materials
}

\author{
Dolgonosov A.M., Khamizov R.Kh., Kolotilina N.K. \\ Vernadsky Institute of Geochemistry and Analytical Chemistry of the Russian Academy of Sciences, Moscow
}

Received 6.11.2018

DOI: https://doi.org/10.17308/sorpchrom.2018.18/607

Nano-sized particles of functional polymers i.e. nano-ion-exchangers (NIEX), are unusual objects which simultaneously behave as the hyper-charged ions and the solid ion exchangers. Due to similar charges, they form very stable colloidal systems. This paper is devoted to theoretical and practical study of the properties of nano-exchangers, methods for their preparation, the technique of experiments being practically unknown, and the opportunities for their application.

The results of dynamic experiments are given for sorption of nano-exchangers and the ions of background solutions on the beds of macro-particles of usual cationic and anionic resins. It is shown how to obtain the NIEX hydrosols with the desired ionic composition, and the concept of the standard state hydrosol is defined. The possibility for solid-phase exchange of counter ions between contacting particles of the same polarity is demonstrated.

The possibilities and advantages of using nano-ion-exchangers in chemical analysis are demonstrated by different examples: preparation of separating phases for ion chromatography, application as modifier in capillary electrophoresis and using in photo-luminescence. The prospects of nano-ion-exchangers for drug delivery are also shown.

Keywords: nano-ion-exchangers; solid-phase ion exchange; ion chromatography; capillary electrophoresis; luminescence; drug delivery.

\section{Нано-ионообменники - новый класс реактивных материалов}

\author{
Долгоносов А.М., Хамизов Р.Х., Колотилина Н.К. \\ Институт геохимии и аналитической химии им. В.И. Вернадского РАН, Москва
}

Полимерные иониты с частицами нанометровых размеров, наноиониты, являются необычными объектами - одновременно гиперзаряженными ионами и ионообменниками, создающими устойчивые водные суспензии. В работе рассмотрены вопросы теоретического и практического исследования свойств наноионитов и способы их получения. Приведены результаты динамических сорбционных экспериментов, в ходе которых осуществлялась сорбция наноионитов и ионов сопутствующих растворов, создавались стандартные состояния наносуспензий. Особенности кинетики ионного обмена, чрезвычайно быстрой в системах с наноионитами, позволили осуществить процесс твердофазного обмена противоионов между ионообменными фазами одинаковой полярности.

Наноиониты имеют уникальные свойства, использование которых в аналитической химии чрезвычайно эффективно. В работе показаны пути развития методов ионной хроматографии и капиллярного электрофореза с применением наноионитов в качестве неподвижных и подвижных фаз, а также демонстрируется способ использования ионообменных микрореакторов для люминесцентного определения тяжелых металлов в природных водах.

Рассмотрены перспективы использования наноионитов для доставки лекарств в больные ткани. Показано, что применение наноионитов при проведении химиотерапии позволяет снизить дозу лекарств в несколько раз.

Ключевые слова: наноразмерные полимерные ионообменники, твердофазный ионный обмен, ионная хроматография, капиллярный электрофорез, люминесценция, транспорт лекарств. 


\section{Introduction}

Ion exchange (IEX) processes are widely used in the world for water treatment, in hydrometallurgy, food industry, biotechnology and other fields. These processes are carried out with using ion exchangers - solid particles of about $0.2-1.0 \mathrm{~mm}$ in size, containing fixed functional groups charged negatively for cationic - and positively for anionic exchangers. In analytical chemistry, ion-exchanging microspheres of dimensions of the order of $10 \mu \mathrm{m}$ are used in columns for ion chromatography, the particles of submicron sizes are also used as the modifiers for the stationary phases. We have no information available in the literature on the use of smaller particles.

This work is devoted to the research in the field of obtaining, studying and applying a new class of chemical substances - nano-scale ion exchangers (NIEX), which are prospective in chemical analysis and in medicine for drug delivery.

The properties of particles of ion-exchange resins of the under-hundred nanometers range have not been studied to the present day. This was due to the laboriousness of synthesizing functionalized nano-polymers, the complexity of working with them and the lack of tasks for their application. Meanwhile, these objects are interesting not only for their obviously high kinetic properties, but also due to the ability to form very stable colloids and combine the properties of hyper-charged ions and solid ion exchangers. Unlike conventional IEX resins, NIEX can pass through microfiltration membranes and some other filtering materials. Large charges of them at small masses make it possible to control their motion and distribution at phase boundaries. Nano-sized ion exchangers can be of great interest not only from practical, but also from the theoretical point of view. For example, the existing mathematical theory of mass-transfer dynamics for bi-disperse systems could be applicable to such objects, if its appropriate generalization would be done. It is also interesting to develop a chemical theory of NIEX, which includes hetero-phase reactions of ion exchange not only on nanoparticles, but also with the nanoparticles themselves as the ions.. The next step is the development of techniques for working with hydrosols of nanoion-exchangers. In many respects, the areas of NIEX application coincide with the already mastered ion exchange branches. These are: analytical and preparative chromatography, deep purification and concentration technologies, chemical synthesis, medicine, and the like. However, the most promising and specific nano-chemical quality of NIEX is combining the properties of solid sorbents and hyper-charged ions, and this intrigues us.

Attempts have been made to synthesize functionalized polymers in form of nanosized particles on the basis of styrene and divinylbenzene [1,2]. The copolymer particles of several tens $\mathrm{nm}$ has been synthesized successfully, but modification with sulfonic or strong-base anionic groups have resulted in their dissolution [1]. From studies like [2], it is possible to estimate the dimensions of the critical nucleus in the synthesis of nano-ionexchangers near $50 \mathrm{~nm}$.

We can consider the opposite, top-down approach in obtaining nano-sized exchangers - by ultrafine grinding coarse materials, but a question arises: how to do it with the use of abrasive surfaces of micrometer roughness? In any way, the problem solution is in improving both the approaches: the bottom-up synthesis from molecules and the disintegration of materials with the desired properties. As to the last approach, not the abrasion but grinding in a ball mill can be used. In this case, at impact action of the ball on micronsized particles, a tiny proportion of fragments being smaller in tens and hundreds times is produced. This method is used in our studies [3], and the problems of preparation, techniques for working with NIEX and the prospects for their application in ion chromatography and medicine are considered in this work. 


\section{of NIEX}

\section{Chart of existence, preparation and physicochemical characteristics}

The main of the first results obtained after starting our experiments was that strong acid or strong base nano-ion-exchangers (NIEXs) did not coagulate in water solutions. The NIEX particles do not require any chemical treatment for making protective shells, they form themselves stable for years colloidal solutions (suspensions).

It is suitable to illustrate the field of existence of non-coagulating nano-sized particles (of any type: protected or not) by the chart shown in Fig. 1.

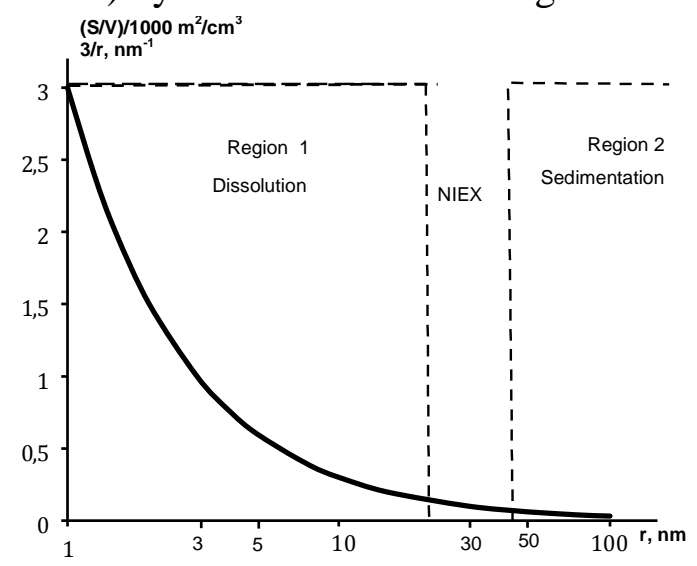

Fig. 1. Chart of the existence of nano-ion-exchangers

Here, the ratio of smooth (projection) surface to a volume $(S / V)$ is pictured dependently on the radius of spherical particle (in logarithmic scale). This ratio is critical and it determines physical and chemical properties, such as diffusion, sedimentation, electroconductivity, catalytic activity and others. Theoretically, the taken boundaries of the chart can be explained that one can start from the radius $1 \mathrm{~nm}$ (with $S / V=3 \cdot 10^{3} \mathrm{~m}^{2} / \mathrm{cm}^{3}$ or $S / V=3 / r=3 \mathrm{~nm}^{-1}$ for spherical particles) and finish with $100 \mathrm{~nm}$, neglecting the values less than $1 \%$ of the starting parameter. From a left part of the figure, the field of NIEX existence is limited by the effect of dissolution of nano-sized functionalized copolymer [1], and this region 1 extends up to an average particle size of $50 \mathrm{~nm}(\mathrm{r}=25 \mathrm{~nm})$. On the right, this theoretical area intersects with the region 2 determined by the sedimentation conditions of large particles. It is possible to analyze this condition from the Brown diffusion sedimentation equilibrium equation, arising from the equality of the corresponding fluxes $J_{D}$ and $J_{\text {sed }}$ :

$$
J_{\text {sed }}=\frac{2 g \Delta \rho r^{2}}{9 \eta} c=\frac{k T}{6 \pi \eta r} \frac{d c}{d H}=J_{D},
$$

where $g$ - acceleration of gravity; $\Delta \rho$ - difference between densities of particle and water; $\eta$ - dynamic viscosity. Solution of (1) gives a formula analogous to a barometric one:

$$
H=\frac{3 k T}{4 \pi r^{3} g \Delta \rho},
$$

where $H$ is the height of the suspension bed along which the concentration of particles increases in $e$ times from the top to the bottom level. For ion exchangers with internal porosity around $50 \%$ and with the true polymer density of $1.2 \mathrm{~g} / \mathrm{cm}^{3}$, the effective density in water is $\left(\mathrm{g} / \mathrm{cm}^{3}\right)$ :

$$
\Delta \rho \approx \varepsilon \rho_{\omega}+(1-\varepsilon) 1.2-\rho_{\omega}=0.1
$$


Let us intake the range of concentrations of functional groups of NIEX particles in hydrosol, being suitable for experimental operations: from $c=10^{-5} \mathrm{~mol} / \mathrm{L}$ to $1 \mathrm{~mol} / \mathrm{L}$. We can estimate a maximal height of the suspension bed inside of which the stable sedimentation-diffusion equilibrium can be kept: $H_{\Sigma}=2.303 \cdot 5 \cdot H$.

In various experiments, it is not convenient to work with the bed height less than $10 \mathrm{~cm}$, and it gives us a critical radius of NIEX to be precipitated around $50 \mathrm{~nm}$. It defines the left boundary of the region 2 in the figure. Thus, the existence area of nano-ionexchangers in the form of stable colloids in the aqueous solution is very narrow, this area (between regions 1 and 2) is approximately limited by particle sizes from 50 to $100 \mathrm{~nm}(25$ $\mathrm{nm}<\mathrm{r}<50 \mathrm{~nm})$.

Preparation of nano-ion-exchangers by the top-down technique

Nano-ion-exchangers are the indirect and minor product of grinding in a ball mill in which the insignificant part of micro-granules can be destroyed under the influence of strong mechanical impacts, and particles of extremely small sizes can be split off from them.

NIEXs were obtained in the form of stable colloids - hydrosols in experiments that included several rather long stages: a) grinding commercial granulated ion exchanger in a ball mill for more than 100 hours; b) suspending the dust product in the pure water and sedimentation in the columns for several days to produce clarified suspension; c) continuous centrifugation of this suspension for several hours with the insulation of transparent colloidal solution, usually, red coloured. The yield of the final product - in terms of the content in the hydrosol obtained was no more than $1 \%$. The coarsely dispersed part of the material remaining after all operations was usually combined, dried and allowed to be regrinded.

In a number of experiments, very stable colloidal systems - hydrosols of sulfonic cation exchanger and quaternary ammonium strong base anion exchanger, both with a styrene copolymer matrix and with $8 \%$ of a crosslinking agent, divinylbenzene, were obtained.

The micrographs of nano-particles (obtained in reflected electrons after drying the single drops of products on a silicon surface) are shown in Fig 2. The particles are irregular in shape, often - in the form of flakes or pyramids with maximum dimensions in the range $50-300 \mathrm{~nm}$. It will be shown below that in terms of their physicochemical properties, in particular, relative surface charge (analogous to $S / V$ ), the sizes of the particles of irregular form correspond to the dimensions of the true nano-spheres from the chart of their existence.

a)

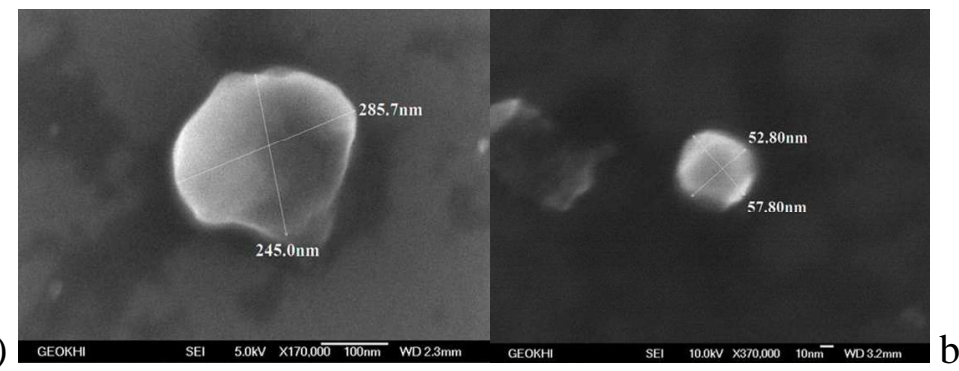

Fig. 2. Electron micrographs of nano-exchangers: a) the largest and smallest particles of cation-exchanger NIK (KU-2); b) the particles of anion-exchanger NIA (AV-17)

As will be shown also, the concentrations of nano-particles in different suspensions produced were varying from 7 to $40 \mathrm{mM}$ of functional groups. 
Relative surface charge of nano-ion-exchangers

The consequence of the sizes of NIEXs in the range of 50-100 nm (for particles of irregular shape the boundaries are spread out to 10-300 $\mathrm{nm}$ ) is the dual nature of NIEXs which are to be both ions and solid ion exchangers. It is important to distinguish between the total and real charge of NIEX. The total charge is equal to the charge of the functional groups of the particle. The actual charge is determined by the amount of fully dissociated functional groups on the surface of the particle. The dissociation is practically complete for strong acid cation- and strong base anion exchangers. Thus, at the interface of the phases, a spatial separation of the fixed charges located on the surface of the particle takes place, and counter-ions are located at some (dynamically) average distance in the direction toward the solution (Fig. 3).

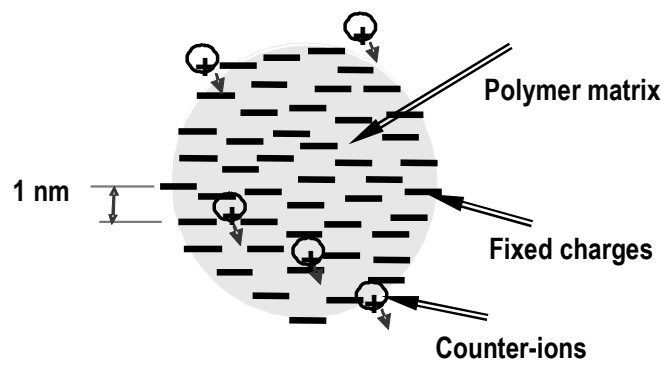

Size of particle $>10 \mathrm{~nm}$

Fig. 3. Uncompensated surface charge, arising due to the dissociation of the functional groups of ion exchanger.

In determining the relative surface charge (RSC), functional groups inside the conditional outer smooth surface sphere are not considered, even if these groups are completely dissociated. For the simplicity, we can consider a cubic particle with a side $D$ (or $2 r$ ) constructed from the small secondary cubes with the side $D=1 \mathrm{~nm}$, each having a single charge. Formula for estimating the dimensionless quantity of relative surface charge will be:

at $D \geq 2 \mathrm{~nm}$ :

$$
R S C=2 k \cdot \frac{D^{2}+D(D-2)+(D-2)^{2}}{D^{3}} \times 100 \%
$$

were $k=1 \mathrm{~nm}$, and it is the relationship between the surface and volume concentrations of charges (functional groups) at a distance between them equal $1 \mathrm{~nm}$,

at $D<2 \mathrm{~nm}$, we deal with one charge, and $\mathrm{RSC}=100 \%$,

at $D \gg>2 \mathrm{~nm}$, up to a coefficient $k=1 \mathrm{~nm}$, the value of RSC become close to the relation of the surface area to the volume of nano-particle shown in Fig.1 (for cubic form, as for sphere of $D=2 r: S / V=6 / D$ in $\mathrm{nm}^{-1}$ or $6000 / D$ in $\mathrm{m}^{2} / \mathrm{cm}^{3}$ ) For example, for a cubic particle with a side of $10 \mathrm{~nm}$ and with an average distance between adjacent functional groups of $1 \mathrm{~nm}$, the total charge in absolute value is estimated in $10^{3} \mathrm{AU}$ (the atomic unit is equal to the charge of the electron), and the actual charge equal to the charge of the surface groups is $488 \mathrm{AU}$, i.e. approximately twice less. For $100 \mathrm{~nm}$ particles, these values are, respectively, $10^{6}$ and $610^{4} \mathrm{AU}$. In the second case, the actual charge is only $6 \%$ of the total one. The ratio of the real to the total charge of the ion exchanger, i.e. RSC, is a quantitative parameter expressing the ionic nature of the particle. Obviously, particles with an RSC less than 5\% ( $D>120 \mathrm{~nm})$ hardly make sense to be considered as the hyper-charged ions. This border, as we see, coincides approximately with the size-limits of the NIEX shown on the chart in Fig. 1 and estimated in term of for spherical particles. 
According to the RSC, the following classification of charged particles is acceptable (Table 1): for RSC less than 5\% - classical ion exchangers (including micro- and macro-sized particles), more than $75 \%$ - low molecular ions, and between 5\% and $75 \%$ - nano-ion-exchangers. The group of micro-ion exchangers assigned to classical ion exchangers is applicable as the chromatographic stationary phases, and macro-ion exchangers are used in ion-exchange technology.

Table 1. The classification of charged particles with respect to the relative surface charge with an average distance between fixed charges inside the ion exchanger of $1 \mathrm{~nm}$

\begin{tabular}{|c|c|c|c|}
\hline Particle & Characteristic sizes, nm & RSC, $\%$ & $\begin{array}{c}\text { State in water and } \\
\text { water solutions }\end{array}$ \\
\hline Ion & $0.1-5$ & $78-100$ & Dissolved \\
\hline Nano-ion-exchanger & $5-50$ & $12-78$ & Dissolved \\
\hline Nano-ion-exchanger & $50-120$ & $5-12$ & $\begin{array}{c}\text { Stable hydrosols and } \\
\text { suspensions }\end{array}$ \\
\hline Micro-ion-exchanger & $120-20000$ & $0.1-5$ & $\begin{array}{c}\text { Suspension and sedi- } \\
\text { ment }\end{array}$ \\
\hline Macro-ion-exchanger & $>20000$ & $<0.1$ & Sediment \\
\hline
\end{tabular}

We can estimate the values of RSC and $S / V$ for nano-particles of irregular form prepared experimentally. For the largest flakes taken in the form of disks or round plates of a diameter $300 \mathrm{~nm}$ and with the thickness of $20 \mathrm{~nm}$, respectively, $\mathrm{RSC}=9 \%$ (as in Table1), or $S / V \times 10^{-3}=0.09 \mathrm{~m}^{2} / \mathrm{cm}^{3}$, according to the radius of spherical particle around $33 \mathrm{~nm}$ (Fig. 1). In both cases, the particles experimentally obtained correspond to the designated regions for NIEXs.

Estimation of surface electric potential of NIEX particles

Taking the above considerations as a basis, it is possible to estimate the surface potential of a NIEX particle in a dilute aqueous solution according to the known density of functional groups in the solid phase - the ion exchange capacity $a_{0}\left(\mathrm{meq} / \mathrm{cm}^{3}\right)$, and the particle diameter $D(\mathrm{~nm})$ : the maximum limit is $\varphi_{s} \sim 10 a_{0} D(\mathrm{mV})$ at a level: $300-1000 \mathrm{mV}$. The actual values of $\varphi_{s}$ strongly depend on the particle size, but in order of magnitude this interval is not so far from the electrokinetic potential (which is little affected by the size) for ion exchangers with strongly dissociative functional groups. For example, for strong base anion exchangers with the distance between two neighboring charges equal $1 \mathrm{~nm}$, it was found zeta potential: $\zeta \sim 250 \mathrm{mV}$ [4]. In this work, streaming potential was measured for homogeneous membrane AMX-SB in $\mathrm{Cl}$-form and very diluted solution of $\mathrm{NaCl}$, and zeta potential was calculated with the use of Helmholtz-Smoluchowski modified equation [5]. At the and, the lower limit of the electrokinetic potential for ion exchangers can be estimated from the jump in the Donnan potential at the interface between phases compared to the bulk of solution an determined by the ratio of the NIEX capacity and the concentration of counter-ions in a mono-component diluted solution. For example, for nano-anionexchanger (NIA) with $a_{0}=1.5 \mathrm{M}$, at $c_{0}=10^{-3} \mathrm{M}$ and $T=298 \mathrm{~K}$ :

$$
\Delta \varphi_{D} \approx \frac{R T}{z F} \ln \frac{a_{0}}{c_{0}} \approx 190 \mathrm{mV}
$$

For NIC ( $z=-1$ for co-ions) with $a_{0}=2.5 \mathrm{M}, \Delta \varphi_{D} \approx-200 \mathrm{mV}$.

All the estimations give a few hundred $\mathrm{mV}$ for zeta potential, this provides high stability of NIEX colloidal systems, which persist for many years. The electrostatic nature of nano-anion- and cation-exchangers determines the fact that the mixing corresponding

Dolgonosov et al. / Сорбционные и хроматографические процессы. 2018. Т. 18. № 6 
hydrosols, stable separately, leads to immediate (in seconds) coagulation of particles. Fig. 4 illustrates the dense branched structures that arise at mixing hydrosols NIA and NIC.

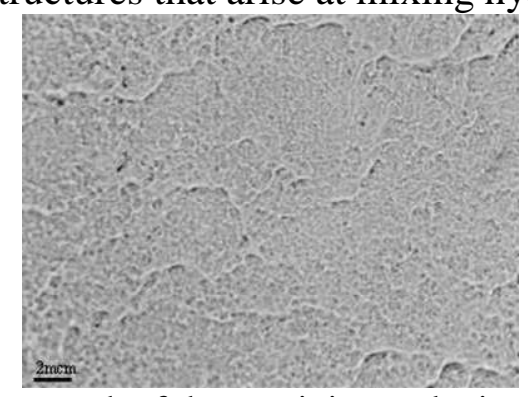

Fig. 4. Micrograph of the precipitate, obtained by mixing of NIEX hydrosols of different polarity.

\section{Concentration of particles}

The concentration of NIEX particles can be assigned to the concentration of functional groups through the capacity of the solid phase:

$$
c_{x} \equiv c_{f g}=c_{s p} a_{0 s p},
$$

where $c_{s p}$ is the concentration of NIEX particles $(\mathrm{g} / \mathrm{L}), a_{0 s p}$ - the capacity of the solid phase $(\mathrm{mol} / \mathrm{g})$, i.e. density of functional groups in the polymer matrix. This value can be constant for particles and is known as the capacity of the initial ion exchanger before the process of obtaining nano-ion-exchangers by grinding. In this case, the concentration of NIEX is conveniently defined as $c_{x}(\mathrm{~mol} / \mathrm{L})$, if necessary, easily recalculated in $c_{f g}$.

Example. A sample of $\mathrm{NIC} / \mathrm{H}$ has a concentration of $10.7 \mathrm{mM}$ according to the results of titration with alkali. Evaporation of $15 \mathrm{ml}$ of the hydrosol (then, suspension) to airdry state gave a precipitate with a mass of $37.9 \mathrm{mg}$, whence the mass concentration of NIC $2.53 \mathrm{~g} / \mathrm{l}$. The ratio of the obtained values gives $4.23 \mathrm{mmol} / \mathrm{g}$, which corresponds to the capacity of the initial cation exchanger KU-2x8.

Electrical conductivity and particle shape.

The ratio $k$ of the electrical conductivity determined by the nano-ion-exchanger in the form of ions $I(\mathrm{NIEX/I)} \mathrm{to} \mathrm{the} \mathrm{electrical} \mathrm{conductivity} \mathrm{of} \mathrm{the} I J$ solution with a concentration $c_{x}$ is:

$$
k=\frac{c_{x} \lambda_{x I}}{c\left(\lambda_{I}+\lambda_{J}\right)}
$$

where $\lambda_{x I}$ is the electrical conductivity per functional NIEX group in the form of ion I. Heavy NIEX particles (in order of $10^{6} \mathrm{Da}$ ) give a negligible contribution to the electrical conductivity, and therefore, its magnitude is determined only by counter-ions I, the number of which is equal to the surface charge. In accordance with the definitions, the equality holds:

$$
\lambda_{x I}=\gamma \lambda_{I}
$$

where $\gamma$ is the relative surface charge of the NIEX particle.

Combining expressions (6-8), we express the SRC through $k$ :

$$
\gamma=\frac{\lambda_{x I}}{\lambda_{I}}=k \frac{c}{c_{x}}\left(1+\frac{\lambda_{J}}{\lambda_{I}}\right)
$$

Example. In the experiment, the electrical conductivity for the hydrosol of NIC/H prepared from $\mathrm{KU}-2-8 / \mathrm{H}$, and the conductivity of $0.025 \mathrm{M} \mathrm{HCl}$ solution were measured. The concentration of NIC in terms of functional groups was found to be $0.038 \mathrm{M}$ by alkali titration. The substitution of the measured value $k=0.35$ together with the equivalent 
electrical conductivity of the ions into the formula (9) gives $\gamma=0.28$. If the particles were spherical, then such a relative charge would correspond to $D=22 \mathrm{~nm}$ (at average distance of $1 \mathrm{~nm}$ between the nearest functional groups). The assumption of the shape of a particle in the form of a tablet of height $h$ gives more realistic values: $h=10, D=50 \mathrm{~nm}$ (in this example).

\section{Kinetics and dynamics of ion exchange processes with nano-ion- exchangers}

The total charge of a NIEX particle is proportional to its mass due to the homogeneity of the distribution of functional groups in the bulk of the polymer. In this connection, the charge/mass ratio, which is a characteristic of the mobility of the particle, can be associated with the effective charge. The diffusion mobility of nanoparticles is proportional to the effective charge. In particular, it is much lower than that of ordinary molecules or ions. Therefore, during the sorption of NIEX by a macro-ion-exchanger of opposite polarity, the convective mass transfer of nanoparticles comes to the fore; it depends strongly on the temperature gradient and the vortex motion of the liquid phase.

Another process, connected with the exchange of ionic forms of NIEX and macroion-exchanger of the same polarity, largely includes internal diffusion. In it, the particle of a NIEX plays the role of a co-ion, hence the characteristic period of achieving equilibrium in such a system includes the sum of the diffusion times inside the macro-ion-exchanger and in the NIEX. The latter value is estimated in the range of tens of ms, which is much lower than the first value. At low ionic strength of the solution, the ion exchange process is characterized by an increased external diffusion region due to strong repulsion of NIEX from the surface of the same polarity.

Ion-exchange dynamic method for operation with NIEX

To work with nano-ion-exchangers, it is convenient to use NIEX in a standard state - in the form of water ions $(\mathrm{NIC} / \mathrm{H}, \mathrm{NIA} / \mathrm{OH})$ against a background of pure water. Such a hydrosol can be easily and quantitatively converted to other ionic forms using acid-base titration keeping the background of pure water. For example, to obtain the sodium form of NIC, an equivalent amount of sodium alkali is to be added to the NIC/H solution; if it is desired to obtain a chloride form of NIA, an equivalent amount of hydrochloric acid is to be used for NIA/OH solution. Therefore, the grinded macro-ion exchangers can be first converted into the form of the corresponding water ions. Unless the methods of restoring standard states are elaborated, the NIEXs will be disposable at their using in IEX processes.

Below are two-letter designations for ion exchangers, where the second letter is $\mathrm{x}$ (from the "exchanger"), and the first letter $A(a)$ or $C(c)$ corresponds to anion-exchanger or cation exchanger, with a capital letter for resins with macro-particles and a lower letter for nano-ion-exchangers.

One can consider a very important task for the chemistry of nano-ion-exchangers: the hydrosol of NIEX with an arbitrary composition must be turned to another hydrosol with any pre-determined ionic form in the appropriate background or in pure water. The solution of this problem is illustrated by the following theoretical scheme.

Let, for definiteness, be given the NIC in the form of $\mathrm{B}^{+}$in equilibrium with the solution of the salt $\mathrm{AB}$. It is required to obtain a NIC in the form of $\mathrm{X}^{+}$in equilibrium with a solution of $\mathrm{XY}$. We perform the following dynamic processes:

$(1+p) A x^{+} Y^{-}+c x^{-} B^{+}+A^{-} B^{+} \Leftrightarrow A x^{+} A^{-}+p A x^{+} c x^{-}+(1-p) c x^{-} B^{+}+(1+p) B^{+} Y^{-}$

where $p$ is the effective charge.

Dolgonosov et al. / Сорбционные и хроматографические процессы. 2018. Т. 18. № 6 
Passing the initial hydrosol through a column with macro-ion-exchanger $\mathrm{Cx}^{-}$in $X$ - form leads to the exchange of counter-ion $B^{+}$giving:

$$
C x^{-} X^{+}+c x^{-} B^{+}+B^{+} Y^{-} \Leftrightarrow C x^{-} B^{+}+c x^{-} X^{+}+X^{+} Y^{-} \text {. }
$$

Such a method gives a fraction $1-p$ of target product $c x^{-} X^{+}$in the solution of $X Y$ with the concentration of NIC by $1+p$ times increased compared to the initial one.

The reaction (10) takes place in a system with two solid phases and the common liquid phase. One of the product of such a solid phase reaction is a nano-composite in which the surface of macro-resin is not blocked, providing the entire volume of its grains for the exchange of counter-ions. The scheme according to the reaction (10), has been implemented in the experiment illustrated by Fig.5. The concentration histories were monitored at passing hydrosol of $\mathrm{KU}-2 / \mathrm{H}$ admixed with the electrolyte $\mathrm{HCl}$ through the column with macro-resin AV-17/OH. Light absorption was measured to get a curve 1 and conductivity of the solution - for a curve 2 . The experiment resulted in anionic capacity $0.95 \mathrm{meq} / \mathrm{mL}$, and about $0.1 \mathrm{meq} / \mathrm{mL}$ for the cationic one.

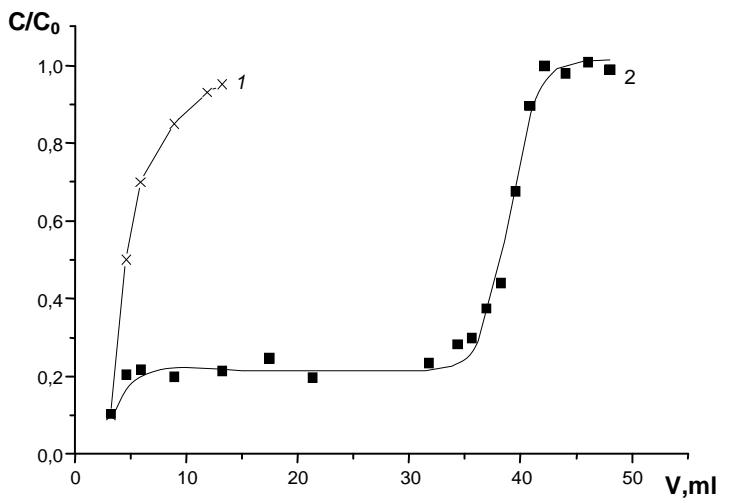

Fig. 5. Concentration histories for nanosuspension NIC KU-2/H $+\mathrm{HCl}$ on the column with macro-resin $\mathrm{AV}-17 / \mathrm{OH}$ : curve 1 for NIC (measured by light absorption), curve 2 for sum $\mathrm{NIC}^{-}+\mathrm{Cl}^{-}$(measured by electro-conductivity). Concentrations at inlet: $0.038 \mathrm{meq} / \mathrm{ml}$ of $\mathrm{NIC} / \mathrm{H}$ and $0.025 \mathrm{M}$ of $\mathrm{HCl}$. Bed volume $1 \mathrm{ml}$. Column diameter 4 $\mathrm{mm}$. Flow rate $0.22 \mathrm{ml} / \mathrm{min}$.

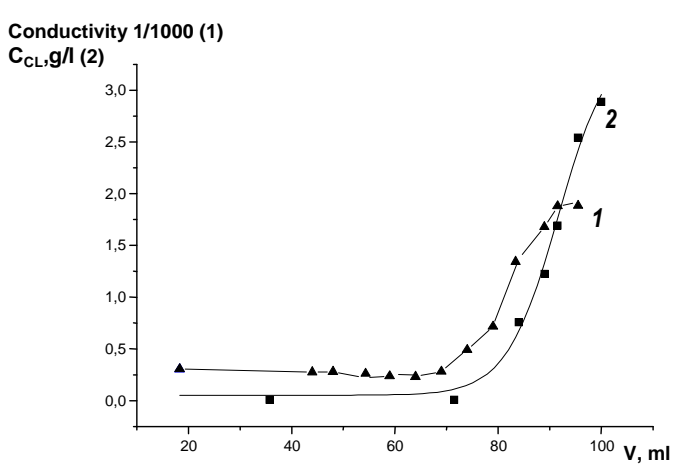

Fig. 6. Concentration histories for the hydrosol: $\mathrm{KU}-2+\mathrm{NaCl}$ and the system of successively arranged columns with macroanion-exchangers $\mathrm{AV}-17(\mathrm{OH})$ and $\mathrm{KU}-2$ (H). Curve 1 for conductivity, curve 2 for chloride concentration.

Reaction (11) in a conjunction with the reaction (10) was experimentally tested at passing nano-suspension KU-2 (NIC) with the electrolyte $\mathrm{NaCl}$ through the system of successively arranged columns with macro-anion-exchangers AV-17 $(\mathrm{OH})$ and KU-2 $(\mathrm{H})$. For the construction of concentration histories, conductivity (curve 1 in Fig.6) and chloride concentration (curve 2) were measured with the use of ion chromatograph. The average concentration of NIC determined by the alkali titration of the effluent fractions in the range of $6-80 \mathrm{ml}$ was found to be $0.038 \mathrm{meq} / \mathrm{mL}$. The reaction (11) without external electrolyte has a form:

$$
C x^{-} X^{+}+c x^{-} B^{+} \stackrel{\mathrm{H}_{2} \mathrm{O}}{\Leftrightarrow} C x^{-} B^{+}+c x^{-} X^{+}
$$

This process is unusual and this implies a direct exchange by ionic forms between solid phases. For the confirmation of principal possibility of the reaction (12), the experiment was carried out in which the hydrosol of NIEX in pure water was used for the transference of counter-ions from one column to the another (Fig. 7). 


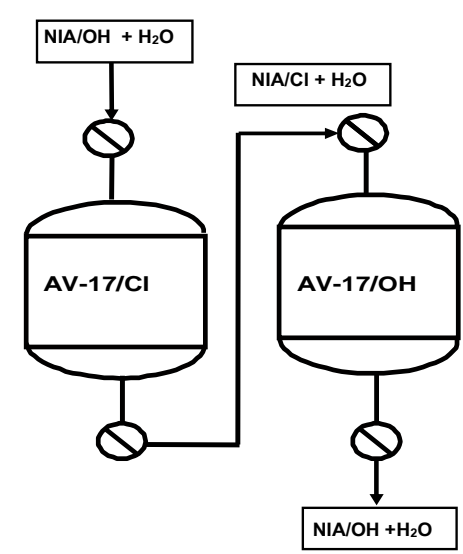

Fig. 7. Laboratory installation for testing the reaction (12). Loading volume $-6 \mathrm{~mL}$, diameter of each column - $4 \mathrm{~mm}$, the hydrosol concentration $-0.0025 \mathrm{M}$, flow rate $0.7 \mathrm{~mL} / \mathrm{min}$. At regeneration, $145 \mathrm{~mL} 0.1 \mathrm{M} \mathrm{NaOH}$ was passed; flow rate: $0.7 \mathrm{~mL} / \mathrm{min}$.

The experimental setup comprised two consecutive columns with the same beds of strong base anion exchanger $\mathrm{AV}-17$ in different initial ionic forms: the first one was in chloride, and the second bed - in hydroxyl form. The hydrosol of NIA AV-17 in OH form was passed through the columns. At the outlet of the second column, the fraction of remained $\mathrm{OH}-$ form was determined by the titration with acid. After passing of the hydrosol of the equivalent amount equal to $10-20 \%$ of the bed capacity, the process was stopped. The second column was regenerated with the alkali solution with measuring the amount of desorbed chlorides. This amount aroused strictly equivalent to the total content (capacity) of passed hydrosol. The experiment clearly showed the transition of chlorides and confirmed the reaction (12). For example, after the passing $50 \mathrm{~mL}$ of the initial hydrosol, the retention of $\mathrm{OH}^{-}$was found to be $0.125 \mathrm{meq}$ ( $2 \%$ of the capacity of the chloride columns). After the regeneration with $145 \mathrm{~mL}$ of $0.1 \mathrm{M} \mathrm{NaOH}, 133$ meqs of chlorides desorbed from the second column were found.

A special case of the reaction (10) is the interaction of hydroxyl form of macro-ionexchanger $\left(Y^{-}=\mathrm{OH}^{-}\right)$with $\mathrm{H}$-form of NIC in water media

$$
A x^{+} \mathrm{OH}^{-}+c x^{-} \mathrm{H}^{+} \Leftrightarrow A x^{+} c x^{-}+\mathrm{H}_{2} \mathrm{O}
$$

The product of the reaction is a nano-composite $A x^{+} c x^{-}$being a bipolar sorbent with thin cation-exchanging layer which can be used as a high efficient phase for ion chromatography. The interaction strengths in the systems: macro-cation-exchanger + NIA and macro-anion-exchanger + NIC exceed many times the forces of interaction of low molecular ions with usual ion exchangers. These systems tend to the state of the nanocomposites in which the macro-ion exchangers behaves as the «host», and NIEX plays the role of the "guest". In the host exchanger, only the outer surface and macro-pores are available to the guest one. As mentioned above for macro-ion-exchanger, the surface capacity is a very small fraction of the total one distributed over the volume, so that the NIEX-guest does not interfere with the ion exchange process on the host.

\section{Application of nano-scale ion exchangers in chemical analysis}

Ion chromatography and capillary electrophoresis are currently well-developed methods, but one can find some problems: expensive and insufficiently effective phases, insufficient selectivity, problems with linearity and sensitivity. These drawbacks result in low productivity and high cost of ion analysis. Some problems can be solved at using NIEX phases as modifiers. The distinguishing feature of them are high equilibrium and 
kinetic properties. Unlike conventional ion exchangers, NIEXs can pass through macroporous membranes and filtering materials. Large charges of nano-ion-exchangers, simultaneously with small masses, makes it possible to control their motion and distribution at phase boundaries.

Ion chromatography. Cation-exchanging chromatography column NACATEX

When creating the cation exchange column NACATEX, we achieved the formation of a structure of the sorption surface, the distinguishing feature of which was fixing the cation-modifying nanoparticles in the pores of the anion exchanging basis [3,6-10]. In our studies, the basic rules and techniques listed below were implemented $[9,10]$.

1. Macro-porous ion exchanger, the surface of which is composed of the intraporous and the outer one, is selected as the substrate (host).

2. The ion exchanger of opposite polarity, with respect to the substrate, with the selectivity required for chromatography, is selected as the modifier (guest).

3. The particle size of the modifier is chosen to be smaller than the pore size of the substrate, to allow the penetration of guest particles into the inner space of the host.

4. The modification of the substrate is carried out in a dynamic mode, for which a hydrosol of the modifier is passed through a chromatographic column filled with a host particles until NIEXs slip through the column.

5. Fixation of the modifying particles of NIEX on the surface of the substrate occurs by the mechanism of interaction of the opposite electric charges.

6. The ionic forms of the substrate and the modifier ensure the neutralization reaction proceeding during their interaction; this forms a sharp front of the dynamic process and provides a strong retention of the nanoparticles in the pores of the substrate.

7. The outer surface of the substrate is cleaned of the modifier by washing with water, ethanol, strong solutions of acids and alkalis.

A micrograph of the base particles is presented in Fig. 8. Inclusions of the modifier, recessed in macro-pores of anion exchanger are visible. This type of surface structure is characterized by the stability of its sorption properties and chemical stability, which is an advantage over the poly-functional silica-based sorbent described in [6]. The analytical properties of the chromatographic column and conditions for separation were tested by the example of determination of alkaline elements and ammonium. The experiment was carried out on the ion chromatograph TSVET-3006 (Russia) with a conductometric detector in a two-column scheme. A suppression column with anion exchanger AB-17 in $\mathrm{OH}$ form was used. The results of the chromatographic experiment are shown in Fig. 9. The detection limits of the analytes were the dozens of $\mathrm{ppb}$.

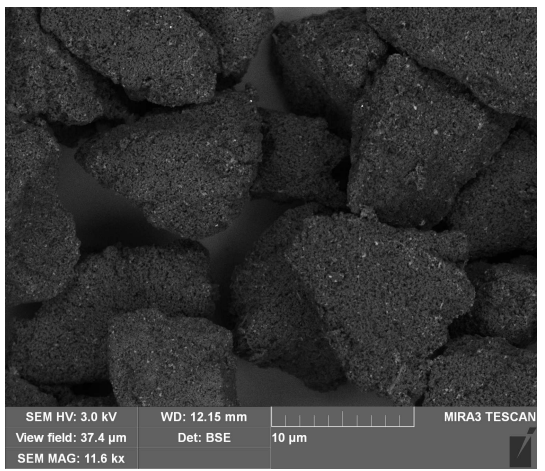

Fig. 8. Electron micrograph of the NACATEX grains. The bright blotches match the modifier particles.

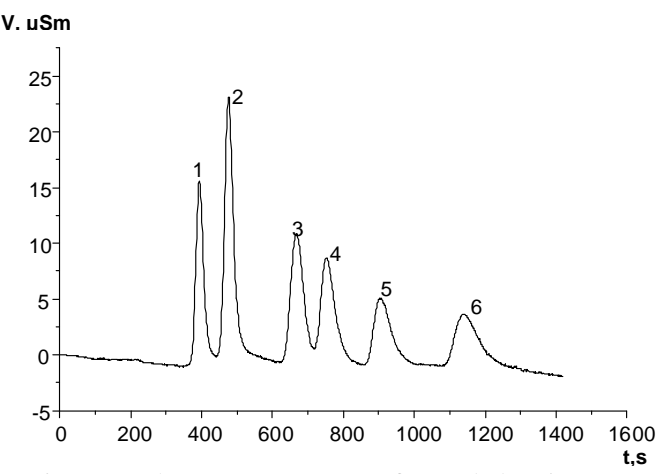

Fig. 9. Chromatogram of model mixture (ppm): $1-\mathrm{Li}^{+}(1), 2-\mathrm{Na}^{+}(5), 3-\mathrm{NH}_{4}^{+}(5), 4-$ $\mathrm{K}^{+}(5), 5-\mathrm{Rb}^{+}(10), 6-\mathrm{Cs}^{+}(15)$. The column is NACATEX $150 \times 4.6$ (i.d.) mm. Eluent: 2.5 $\mathrm{mM} \mathrm{HNO}_{3}$; flow rate $1.5 \mathrm{ml} / \mathrm{min}$. 


\section{Capillary electrophoresis}

As it was published in [11,12], the NIA prepared by us was used as a modifier of the background electrolyte in capillary electrophoresis to separate inorganic anions. The influence of the concentration of nano-ion-exchanger in the composition of the background electrolyte on the magnitude and sign of the electro-osmotic flow was revealed, as well as the efficiency and resolution factors at the electrophoretic separation of inorganic anions. It was established for the first time that the addition of a highly basic nano-anion-exchanger to the background electrolyte in a concentration exceeding $0.01 \mathrm{mM}$ in functional groups leads to reversal of the electro-osmotic flow. This indicates a dynamic modification of the walls of the quartz capillary and leads to an increase in the efficiency and selectivity of the separation of inorganic anions in comparison with the results obtained with the traditional cationic agent cetyl-trimethyl-ammonium bromide. A selective and highly efficient electrophoretic separation of eight inorganic anions using NIA was demonstrated (Fig. 10). The technique was implemented to determine inorganic anions in urine (Fig. 11).

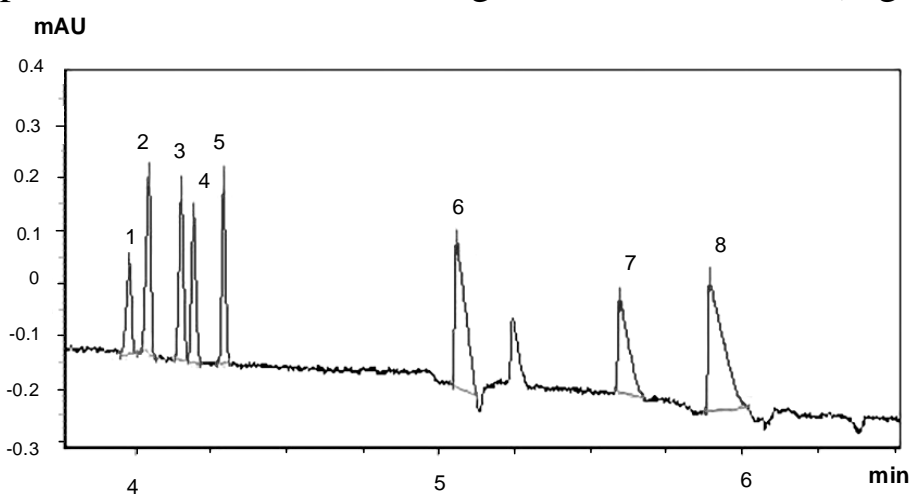

Fig. 10. Electropherogram of the mixture of anions: 1- $\mathrm{Br}^{-}, 2-\mathrm{Cl}^{-}, 3-\mathrm{NO}_{2}{ }^{-}, 4-\mathrm{SO}_{4}{ }^{-}, 5-\mathrm{NO}_{3}{ }^{-}$, 6- $\mathrm{F}^{-}, 7-\mathrm{HPO}_{4}{ }^{2-}, 8-\mathrm{CO}_{3}^{2-}$. Indirect UV detection at $254 \mathrm{~nm}$. Background electrolyte: $5 \mathrm{mM} \mathrm{CrO}_{3}$, $40 \mathrm{mM}$ DEA, $0.05 \mathrm{mM}$ NIA, $10 \%(\mathrm{v} / \mathrm{v})$ of methanol. (With the permission of the authors $[11,12]$ ).

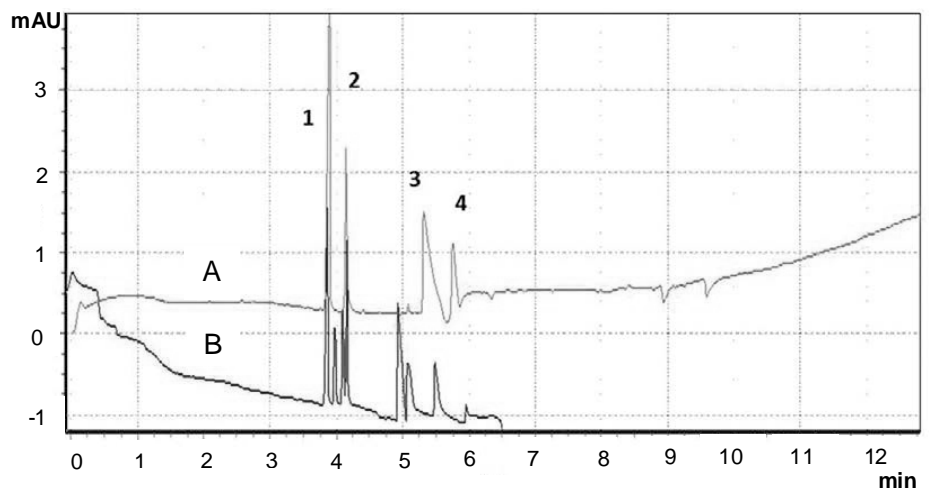

Fig. 11. Electropherograms of a urine sample (A), diluted 200 times with deionized water (pH of sample 6.5): $1-\mathrm{Cl}^{-}, 2-\mathrm{SO}_{4}{ }^{2-}, 3-\mathrm{HPO}_{4}{ }^{2-}, 4-\mathrm{CO}_{3}{ }^{2-}$; and a model anion mixture (B). The conditions are the same as for Fig. 10.

\section{Photoluminescence of polystyrene NIEX}

The presence of dissolved impurities of heavy metals in natural waters is one of the important environmental problems. Very strict standards for the maximum allowable concentrations less than $1 \mathrm{ppb}$ are set for many heavy metals. Analysis of such metal contents is laborious and expensive, and it is not always justified for the purpose of environmental monitoring. The photoluminescence method of analysis is very promising owing its sensitivity and simplicity, but the direct determination of traces of heavy metals is hard to be realized. The problem can be solved with using NIEX particles as the luminescence emitting points, simultaneously concentrating the metal ions. The method of sensitive determi- 
nation is based on the effect of quenching of luminescence of NIEX by heavy metals. Highly diluted solutions of NIEXs on polystyrene type can be used as the luminophores. The highest signal corresponds to the NIEX $(\mathrm{H})$ in the standard state. Alkali and alkaliearth elements, widespread in nature, do not influence on this signal. However, transition metal atoms extinguish the luminescence [13]. Particles of NIEX concentrate highly such ions, and so, the samples containing NIEX can be analyzed by luminescence method with good sensitivity [14]. A new approach for the analysis of heavy metals in water, developed on the principle of quenching luminescence, is an indirect (differential) method with a limited dynamic range (1-2 orders of magnitude of an analyte concentration), and this can be attributed to its shortcomings. However, its advantages lie in the ability to move the dynamic range by the choice of the quantity of the NIEX hydrosols to be dozed and in the versatility of the method with respect to various heavy metals.

Example. Preliminarily, NIA was transformed into the form of anions of sulfosalicylic acid (SSa). Model solutions containing $26 \mu \mathrm{M}$ of NIA/SSa and 0.4-2 $\mu \mathrm{M}$ of $\mathrm{Cu}^{2+}$ were prepared. A spectro-fluorimeter with a gap of $10 \mathrm{~nm}$ had an excitation band of 272 $\mathrm{nm}$. The emission maximum corresponded to $405 \mathrm{~nm}$ (Fig. 12a).

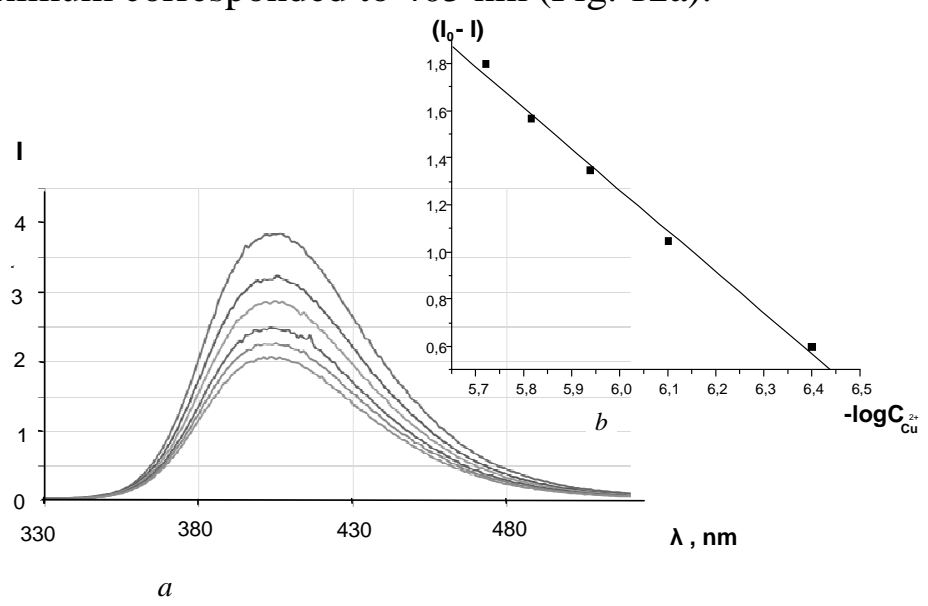

Fig. 12. Luminescence spectra of NIA/SSa with the intensities decreasing with the concentration of sorbed $\mathrm{Cu}^{2+}(a)$. Calibration graph for the determination of $\mathrm{Cu}$ - ions by the luminescence method with nano-ion-exchanger $(b)$.

An analytical signal for the presence of $\mathrm{Cu}$ - ions was the difference between the maxima of the spectra of water solution of NIA/SSa $\left(I_{0}\right)$ and the sample. Figure 12b shows a calibration graph for the system under consideration. The equation of calibration curve for copper concentration $C_{\mathrm{Cu}^{2+}}(\mathrm{mol} / \mathrm{L})$ is $I_{0}-I=11.71+\log C_{\mathrm{Cu}^{2+}}$.

\section{Prospects for medical application of NIEXs}

A large body of literature is devoted to the problem of targeted delivery of drugs by the use of nanoparticles. Some articles describe the application of inorganic nanoparticles $[15,16]$, others - polymeric nanoparticles [17]. However, we could not find any sources that describe the application of nan-oion-exchangers for these purposes. The main characteristics of drug-suppliers are: the size, shape, surface properties and stability of particles.

Size. A number of publications specified particle diameters of 200-250 nm, as the upper limit

Form. Spherical particles have less ability to move across the vessel wall in comparison with particles of irregular shape. 
Sorption properties. The main qualities are the capacity of a supplier and the force of holding particles of drug molecules.

Target delivery. An important quality is the ability of the supplier to release the drug in the place of destination.

Mechanical and biochemical stability. The lifetime of the particles in the body of the supplier must be greater than the characteristic period of pharmacokinetics. Material of the supplier and the products of its metabolism should not be poisonous to the body.

Based on all the listed characteristics, including the biocompatibility with living organisms, it is possible to allocate NIEX as the promising drug-suppliers into diseased tissues, especially for cancer curing. Opportunity of the saturation of ion exchanger nanoparticles by ionic forms of drugs may be implemented by using the special ion exchange columns or by their accurate dosing with form non-toxic products. According to the properties and sizes, nano-ion-exchangers are the solid multicharged microreactors, selectively penetrating into the enlarged pores of diseased tissue. Owing to these qualities, called in the literature EPR-effect (enhanced permeability and retention), the NIEXs can serve as the effective means for drug delivery. Due to hypercharge, a small number of NIEX can carry a large amount of drugs.

Example. Preparation and testing of a sample of nano-cation-exchanger (NIC) treated with doxorubicin cations (the "NICDOR sample") [18].

The initial solution was a NIC hydrosol in the form of hydrogen ions NIC/H with the particle maximum sizes of 50-300 $\mathrm{nm}$ and with the concentration a functional group: $0.007 \mathrm{M}$ (concentration of polymer particles: $1.35 \mathrm{~g} / \mathrm{L}$ ).

Doxorubicin $\mathrm{C} 27 \mathrm{H} 29 \mathrm{O} 11$ is soluble in water with the formation of a protonated cationic form, it is stable in a weakly acidic and neutral medium (at $\mathrm{pH}$ range from 3 to 7). One commercial bottle of Doxorubicin-LENS contained $10 \mathrm{mg}$ of doxorubicin and $40 \mathrm{mg}$ of mannitol. The saturation of NIC hydrosol with doxorubicin was performed, as follows: $12.3 \mathrm{ml}$ of the $\mathrm{HS}$ of $\mathrm{NIC} / \mathrm{H}$ was added to the contents of 5 bottles of the medicinal substance «Doxorubicin-LENS». The powder was dissolved in the hydrosol when heated in a water bath and after a day, a mix was filtered through a blue tape paper filter. Insoluble residue of the powder was $10 \%$ of the initial weight. The concentration of doxorubicin of $3.7 \mathrm{mg} / \mathrm{mL}(6.4 \mathrm{mmol})$, and mannitol of $14.6 \mathrm{mg} / \mathrm{mL}$ were obtained in a final modified hydrosol. The obtained sample was called «NICDOR».

The test results of the NICDOR sample in vitro on HeLa culture cells under incubation conditions for 48 hours are presented in Table 2 in comparison with the direct use of the doxorubicin preparation.

Table 2. Results of testing the NICDOR-preparation in comparison with the pure doxorubicin.

\begin{tabular}{|c|c|c|c|}
\hline \multicolumn{2}{|c|}{ NICDOR sample } & \multicolumn{2}{c|}{ Pure doxorubicin } \\
\hline $\mathrm{C}, \mathrm{M}$ & HeLa cell viability, \% & $\mathrm{C}, \mathrm{M}$ & HeLa cell viability, \% \\
\hline $6.4 \cdot 10^{-4}$ & 27.3 & $1.0 \cdot 10^{-4}$ & 41.4 \\
\hline $6.4 \cdot 10^{-5}$ & 16 & $1.0 \cdot 10^{-5}$ & 52.2 \\
\hline $6.4 \cdot 10^{-6}$ & 10.6 & $1.0 \cdot 10^{-6}$ & 68.5 \\
\hline
\end{tabular}

As it shown, he efficacy of doxorubicin in the hydrosol of NIC nanoparticles is 3 to 6 times higher than the same doze of pure doxorubicin. This effect is associated with the concentration of the drug component on the ion-exchange nanoparticles. This allows to reduce the concentration of toxic drugs in the course of chemotherapy in 3-6 times. 
In preliminary studies in collaboration with the Pirogov Russian National Research Medical University, the satisfactory properties of the NIC and NIA, as the suppliers of drugs, were confirmed [18].

\section{Conclusion}

Thus, the paper shows that:

- It is possible to obtain a new class of chemical substances - nano-scale ion exchangers (NIEX) in the form of stable in time suspensions of two, cationic NIC and anionic NIA types:

- NIEXs simultaneously show dual physicochemical properties of dissolved hypercharged ions and microscopic solid ion exchangers capable to a solid-phase ion exchange;

- application of NIEX can solve many problems of increasing the efficiency, speed and sensitivity of analytical chemistry methods in the field of ion analysis, in particular, ion chromatography, capillary electrophoresis and photoluminescence.

- NIEXs are prospective for drug delivery owing to their sorption properties, mechanical and biochemical stability.

The authors are grateful to the colleagues from the St.-Petersburg State University: Kartsova L.A., Makeeva D.V. and Polikarpova D.A. for studying NIEX in the field of capillary electrophoresis. Many thanks to Shimanovskiy N.L., Semeykin A.V. from the Pirogov Russian National Research Medical University for collaboration.

This research is financial supported by the Program «Fundamentals and New Effective Methods of Chemical Analysis» of the RAS Presidium.

\section{References}

1. Turner S.R., Weiss R.A., Lundberg R.D., $J$. Polym. Sci: Polym. Chem., 1985, Vol. 23, pp. 535-548.

2. Brijmohan S.B., Swier S., Weiss R.A., Shaw M.T., Ind. Eng. Chem. Res., 2005, Vol. 44, pp. 8039-8045.

3. Patent RF №2499628, A.M. Dolgonosov, N.K. Kolotilina, M.S. Yadykov, Method for preparing high-performance columns for ion chromatography, Bulletin "Inventions. Utility Models" №33, 27.11.2013 (in Russian).

4. Nebavskaya K.A., Sarapulova V.V., Sabbatovskiy K.G., Sobolev V.D. et al., J. Membrane Sci., 2017, Vol. 523, pp. 36-44.

5. Yaroshchuk A., Ribitsch V., Langmuir, 2002, Vol. 18, pp. 2036-2038.

6. Liu X., Pohl C., Woodruff A., Chen J., J. Chromatogr. A, 2011, Vol 1218, pp. 3407-3412.

7. Small H., Stevens T., Bauman W., Anal. Chem., 1975, Vol. 47, pp. 1801-1809.

8. Sarzanini C., J. Chromatogr. A, 2002, Vol. 956, pp. 3-13.

9. Dolgonosov A.M., Khamizov R.Kh., Properties and application of nano-ion-exchangers in Ion Exchange - a Continuing Success Story,
Extended Abstracts, M.Cox (Eds), Robinson College Publ.,Cambridge, 2016, pp. 135-136.

10. Dolgonosov A.M., Kolotilina N.K., Yadykov M.S., Burmistrov A.A., J. Anal. Chem., 2013, Vol. 68, pp. 444-449.

11. Dzema D.V., Kartsova L.A., Polikarpova D.A., Analitika i kontrol [Analytics and Control], 2017, Vol. 21, pp. 41-48 (in Russian).

12. Polikarpova D., Makeeva D., Kartsova L., Dolgonosov A. et al., Talanta, 2018, Vol. 188, pp. 744-749.

13. Farzin L., Shamsipur M., Sheibani Sh., Talanta, 2017,Vol. 174, pp. 619-627.

14. Dolgonosov A.M., Khamizov R.Kh., Kolotilina N.K., Shaikhina S.U. et al., Sorbtsionnye $i$ khromatograficheskie protsessy, 2016, Vol. 16, pp. 400-414. (in Russian).

15. Li J., Wang Y., Liang R., et al., Nanomedicine, 2015, Vol. 11, pp. 769-794

16. Starostin K.M., Olenin A.Yu., Fedotcheva T.A., Shirokikh K.E. et al., Bulletin of Russian State Medical University, 2015, Vol. 4, pp. 5864. 
17. Vrignaud S., Benoit J.P., Saulnier P., Biomaterials, 2011, Vol. 322, pp. 8593-8604.

18. Patent RF №2635865, A.M. Dolgonosov, N.K. Kolotilina, R.Kh. Khamizov, N.L .Shimanovskiy, A.V. Semeykin, Method of pre-

Долгоносов Анатолий Михайлович д.Х.н., ведущий научный сотрудник, лаборатория сорбционных методов, ГЕОХИ РАН

Хамизов Руслан Хажсетович - д.Х.н., зав. лабораторией сорбционных методов, ГЕОХИ $\mathrm{PAH}$

Колотилина Надежда Константиновна научный сотрудник, лаборатория сорбционных методов, ГЕОХИ РАН paring nanoparticles of polystirene ionexchangers for delivery of anti-tumor preparates, Bulletin "Inventions. Utility Models" No 32, 16.11.2017 (in Russian).

Dolgonosov Anatoly M. - Dr.Sci.(Chem.), Leading scientific associate, Lab of Sorption Methods, GEOKHI RAS, amdolgo@mail.ru.

Khamizov Ruslan Kh. - Dr.Sci.(Chem.), Chief of Lab of Sorption Methods, GEOKHI RAS

Kolotilina Nadezhda K. - Scientific associate, Lab of Sorption Methods, GEOKHI RAS 